\title{
Kajian risiko usaha tani padi di Indonesia
}

\author{
Study of rice farming risk in Indonesia \\ Marten Umbu Kaleka ${ }^{1 *}$, Elita Maulida ${ }^{1)}$, Egidius Taek ${ }^{1)}$, I Putu Edi Swastawan ${ }^{1)}$, \\ Gede Mekse Korri Arisena ${ }^{1)}$ \\ Program Studi Magister Agribisnis, Fakultas Pertanian, Universitas Udayana, Kota Denpasar, Bali \\ *E-mail korespondensi: marthenkaleka13@gmail.com
}

Informasi artikel: Dikirim: 03/04/2020 Ditinjau: $11 / 04 / 2020$ Disetujui: 30/07/2020

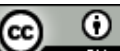

Copyright (c) 2020 Marten Umbu Kaleka Elita Maulida, Egidius Taek, I Putu Edi Swastawan4), Gede Mekse Korri Arisena
ABSTRACT: This study aims to determine: 1) the factors that influence rice farming in Indonesia; 2) the risk of rice farming in Indonesia; and 3) management of risk in farming in Indonesia. The basic method used in this research is study literature. The results of the study showed that the factors affecting the production of rice farming in Indonesia with various conditions were land area, fertilizer costs, pesticides, labor, seeds / seeds, age of farmers, capital, and counseling. The dominant risk factor is land area besides that, the potential risk factors for production are natural disasters, weather and climate, pests, topology, and capital. There are differences in risk of rice production among others cropping patterns, income perspectives, and land area. Risk management of rice farming is adjusted based on risk perspective and AUTP. In the internal aspect, risks can be anticipated through increasing the capacity of farmers, in the external aspect the risk is still possible to be overcome by AUTP.

Keywords: Farming, rice, risk

ABSTRAK: Penelitian ini bertujuan untuk mengetahui: 1) faktor-faktor yang mempengaruhi usaha tani padi di Indonesia; 2) risiko usaha tani padi di Indonesia; dan 3) penanggulangan risiko usaha tani di Indonesia. Metode dasar yang digunakan dalam penelitian ini adalah study literatur. Hasil kajian menunjukkan bahwa faktor yang mempengaruhi produksi usaha tani padi di Indonesia dengan berbagai kondisi adalah luas lahan, biaya pupuk, pestisida, tenaga kerja, bibit/benih, umur petani, modal, dan penyuluhan. Faktor risiko dominan adalah luas lahan di samping itu, faktor potensial risiko produksi adalah bencana alam, cuaca dan iklim, OPT, topologi, dan permodalan. Terdapat perbedaan risiko produksi padi antara lain pola tanam, perspektif pendapatan, dan luas lahan. Penanggulangan risiko usaha tani padi disesuaikan berdasarkan perspektif risiko dan AUTP. Pada aspek internal risiko dapat diantisipasi melalui peningkatan kapasitas petani, pada aspek eksternal risiko masih memungkinkan untuk ditanggulangi dengan AUTP.

Kata Kunci: Padi, risiko, usaha tani

Sitasi: Kaleka, M. U., Maulida, E., Taek, E., Swastawan, I. P. E., \& Arisena, G. M. K. (2020). Kajian risiko usaha tani padi di Indonesia. AGROMIX, 11(2), 166-176. https://doi.org/10.35891/agx.v11i2.1928

\section{PENDAHULUAN}

Padi merupakan salah satu komoditas tanaman pangan yang berperan penting dalam memenuhi kebutuhan primer masyarakat Indonesia, hampir $80 \%$ petani di Negara ini merupakan petani padi (Latham 2013; Mariyono, 2015; Saragih dkk., 2018). Selain diolah menjadi nasi, padi juga dapat diolah menjadi tepung. Salah satu manfaat padi adalah sebagai sumber karbohidrat bagi tubuh (Moongngarm dkk., 2012; Umadevi dkk., 2012). Padi juga banyak mengandung nutrisi yang diperlukan oleh tubuh di antaranya adalah serat, lemak, protein, air, magnesium, kalsium, potassium, fosfor, zat besi, mangan, vitamin B1, vitamin B2, vitamin B3, vitamin B5, vitamin 
B6, dan vitamin B9. Dalam usaha tani padi fungsi produksi menjadi penting, Fungsi produksi adalah hubungan antara output fisik dengan input-input fisik. Konsep tersebut didefinisikan sebagai persamaan matematika yang menunjukkan kuantitas maksimum output yang dapat dihasilkan dari serangkaian input (Miller \& Meiners, 2000).

Tingginya permintaan terhadap padi dapat terlihat dari peningkatan jumlah konsumsi masyarakat terhadap produk turunan komoditas tersebut. Data yang dipublikasikan oleh Badan Pusat Statistik Indonesia mencatat adanya kenaikan harga gabah kering panen (GKP) sebesar 2,29 persen menjadi Rp 5.215 per kilogram (kg) pada Desember 2019. Adapun untuk harga gabah kering giling (GKG) di tingkat penggilingan naik 2,11 persen menjadi Rp 5.313 per kg jika dibandingkan dengan harga gabah kualitas yang sama pada bulan sebelumnya. Secara lebih rinci, BPS mencatatkan harga rata-rata GKG di tingkat petani Rp 5.775 per kg atau naik 2,76 persen dan di tingkat penggilingan $\mathrm{Rp} 5.886$ per kilogram atau naik 2,76 persen. Sementara untuk harga gabah kualitas rendah di tingkat petani Rp 4.633 per $\mathrm{kg}$ atau turun 0,49 persen dan di tingkat penggilingan $\mathrm{Rp} 4.271$ per $\mathrm{kg}$ atau turun 0,34 persen (Badan Pusat Statistik [BPS], 2012).

Menurut Kurniati (2014), masalah produksi berkenaan dengan sifat usaha tani yang selalu tergantung pada alam didukung faktor risiko yang menyebabkan tingginya peluang-peluang untuk terjadinya kegagalan produksi, sehingga berakumulasi pada risiko rendahnya pendapatan yang diterima oleh petani. Risiko yang dihadapi petani padi dapat berupa risiko hasil atau risiko produksi, risiko harga jual produksi, dan risiko pendapatan. Risiko hasil atau produksi mungkin ditimbulkan antara lain karena adanya serangan hama penyakit, kondisi cuaca atau alam, pasokan air yang bermasalah, dan variasi input yang digunakan. Kondisi alam terindikasi sangat berpengaruh terhadap variasi hasil, misalnya dengan kondisi curah hujan yang sangat besar ataupun sangat kecil, bisa menimbulkan gagal panen. Keadaan cuaca yang tidak dapat diprediksi sering kali menjadi penyebab turunnya produksi dan produktivitas tanaman padi yang dihasilkan oleh petani. Selain kondisi alam (cuaca), bahwa lahan; benih; Urea; herbisida; tenaga kerja; juga terindikasi berpengaruh nyata terhadap produksi pertanian padi sawah (Mamilianti dkk., 2019; Suharyanto dkk., 2016; Zakirin dkk., 2013).

Manajemen risiko adalah cara-cara yang digunakan untuk menangani berbagai permasalahan yang disebabkan oleh risiko, disebut juga suatu cara untuk menangani masalah-masalah yang mungkin timbul karena adanya ketidakpastian. Salah satu cara yang dilakukan petani dalam mengatasi risiko adalah petani terlebih dahulu membuat perencanaan bersama kelompok tani dan penyuluh 
pertanian. Pada saat masa produksi apabila terserang hama dan penyakit petani lebih banyak memilih untuk membasmi hama dengan menggunakan pestisida yang lebih cepat dan terbukti, walaupun petani sudah mengetahui dampaknya (Saputra, 2017). Penyuluhan sangat berpengaruh positif terhadap Pendapatan Petani, sehingga perlu penambahan intensitas penyuluhan pada setiap petani (Suprapto, 2010). Risiko usaha tani padi juga disebutkan dalam penelitian Saragih dkk. (2018), menerangkan bahwa batas probabilitas/kemungkinan terjadinya risiko sebesar $40 \%$, sehingga probabilitas $>40 \%$ akan tergolong ke probabilitas yang tinggi sedangkan $<40 \%$ akan tergolong probabilitas yang rendah.

Penelitian ini perlu dilakukan guna merangkum, membandingkan, dan melihat kembali hasil penelitian terdahulu dalam menangani risiko usaha tani padi dengan berbagi macam pengendalian risiko yang pernah dilakukan oleh petani padi di Indonesia. Tujuan penelitian ini adalah untuk mengetahui: 1) faktor-faktor yang mempengaruhi usaha tani padi di Indonesia; 2) risiko usaha tani padi di Indonesia; dan 3) penanggulangan risiko usaha tani di Indonesia. Hasil analisis tersebut nantinya diharapkan dapat menjadi acuan bagi pengusaha tani padi di Indonesia.

\section{METODE}

Metode penelitian yang digunakan adalah penelitian kualitatif. Jenis data yang digunakan adalah data sekunder yang bersumber dari jurnal, penelitian terdahulu, internet dan instansi pemerintah atau lembaga-lembaga yang terkait dengan pengkajian ini. Metode pengumpulan data adalah studi pustaka. Metode yang digunakan dalam pengkajian ini adalah studi literatur. Menurut Zed (2008), pada riset pustaka, penelusuran pustaka tidak hanya untuk langkah awal menyiapkan kerangka penelitian (research design) akan tetapi sekaligus memanfaatkan sumber-sumber perpustakaan untuk memperoleh data penelitian. Data yang diperoleh dikompilasi, dianalisis, sehingga mendapatkan kesimpulan mengenai risiko usaha tani padi di Indonesia.

\section{HASIL DAN PEMBAHASAN}

Faktor-faktor yang mempengaruhi usaha tani padi di Indonesia

Suprapto (2010) menyatakan bahwa secara bersama-sama (simultan) luas lahan, modal, biaya tenaga, biaya pupuk, biaya bibit, biaya pestisida, dan penyuluhan mempengaruhi pendapatan petani. Faktorfaktor yang secara individual (parsial) memiliki pengaruh signifikan terhadap usaha tani padi organik di Kabupaten Sragen yaitu: a) luas lahan; b) modal; c) biaya pupuk; dan d) penyuluhan. Faktor-faktor lain yang secara 
parsial tidak berpengaruh signifikan yaitu: a) biaya tenaga kerja; b) biaya bibit; dan c) biaya pestisida. Berdasarkan seluruh faktor-faktor tersebut, faktor yang paling dominan mempengaruhi usaha tani padi organik di Kabupaten Sragen adalah luas lahan.

Selanjutnya Rama, dkk. (2016) menyatakan faktor-faktor yang berpengaruh pada produksi padi lahan basah yaitu: a) luas lahan, b) benih, c) urea, d) herbisida, dan e) tenaga kerja keluarga, sedangkan faktor lain tidak berpengaruh. Sementara itu faktor-faktor yang mempengaruhi produksi padi pada lahan kering yaitu: a) luas lahan, b) herbisida, c) jumlah tenaga kerja keluarga, dan d) umur, sedangkan faktor lain seperti benih dan pendidikan tidak berpengaruh.

Sedangkan Suharyanto dkk. (2016) faktor yang mempengaruhi risiko produksi usaha tani padi sawah di Bali berdasarkan Hasil uji $t$ menunjukkan bahwa koefisien regresi yang berpengaruh nyata terhadap produksi padi sawah adalah lahan, benih, pupuk $N$, pupuk $P$, pupuk organik, tenaga kerja, musim tanam dan status lahan. Hal ini berarti setiap penambahan atau pengurangan faktor produksi tersebut akan menaikkan produksi padi sawah. Faktor lain adalah tingkat partisipasi petani secara kuantitatif dalam menggunakan pupuk organik masih relatif rendah. Hasil analisis statistik menunjukkan bahwa penggunaan pupuk organik secara nyata dapat menurunkan risiko produksi padi sawah, hal ini diduga karena pemakaian pupuk kimia dalam waktu yang lama dan dalam jumlah yang tinggi dengan tidak diimbangi dengan penggunaan pupuk organik akan berdampak terhadap kualitas dan kesuburan tanah. Menurut Zakirin dkk. (2013) Faktor-faktor yang mempengaruhi produksi padi adalah lahan, benih, Urea, herbisida, tenaga kerja, umur petani, dan dummy tipe luapan B. Setiap penambahan luas lahan $1 \%$ akan menambah produksi padi $0.0342 \%$. Setiap penambahan benih $1 \%$ akan diikuti kenaikan produksi padi 0,1054\%. Setiap kenaikan Urea 1\% akan menaikkan produksi padi $0.0576 \%$. Setiap bertambahnya herbisida 1\% akan diikuti peningkatan produksi padi $0.0825 \%$. Setiap peningkatan tenaga kerja \% akan menaikkan produksi $0.0165 \%$. Semakin bertambah umur petani sampai batas tertentu (periode usia produktif) produksi padi semakin meningkat. Sementara itu Faktor-faktor yang mempengaruhi risiko produksi padi adalah lahan dan benih dengan pengaruh negatif. Setiap penambahan lahan $1 \%$ akan menurunkan risiko produksi $1.1126 \%$. Setiap penambahan benih $1 \%$ akan menurunkan risiko produksi $1.72 \%$.

Hasil penelitian yang telah dirangkum memiliki komoditas serupa, namun dengan kondisi yang berbeda (beragam). Mulai dari padi organik, padi secara umum, padi pada lahan basah, padi lahan kering, sampai dengan padi pada lahan pasang surut sudah pernah diteliti. Jika dirangkum berdasarkan hasil-hasil 
penelitian tersebut, faktor-faktor yang mempengaruhi produksi usaha tani padi di Indonesia dengan berbagai kondisi, yaitu; 1) luas lahan; 2) biaya pupuk; 3) pestisida; 4) tenaga kerja; 5) bibit/benih; 6) umur; 7) modal; 8) musim tanam; 9) status lahan dan 10) penyuluhan. Berdasarkan faktor-faktor tersebut dicari faktor yang paling berpengaruh melalui analisa faktor yang paling sering muncul pada hasil penelitian dengan kondisi penanaman yang beragam adalah 1) luas lahan; 2) pupuk dan 3) pestisida.

\section{Risiko usaha tani padi}

Saputra (2017) macam-macam risiko yang dihadapi petani padi di sekitar daerah perbukitan adalah: 1) bencana alam (seperti longsor dan kekeringan); 2) perubahan cuaca dan iklim (seperti lebih lamanya musim kemarau daripada musim hujan); 3) gangguan OPT (serangan hama wereng); 4) kesulitan pengolahan lahan karena tidak bisa dilalui oleh traktor; 5) mencari pinjaman modal yang sulit. Risiko pasar/harga juga berpengaruh, harga gabah yang fluktuatif membuat petani ragu untuk menjual hasil usaha taninya sehingga Petani mempunyai persepsi buruk terhadap risiko karena menganggap risiko merupakan suatu kejadian yang sangat mengganggu jalannya usaha tani mereka, ditambah dengan risiko institusi yang berasal dari lembaga/pemerintahan yang tidak melakukan pengawasan dan penetapan kebijakan harga yang menurut petani kurang memihak, serta terbatasnya fasilitas pertanian seperti jaringan irigasi, jalan, gudang, dll.

Risiko usaha tani padi dapat dianalisa melalui perbandingan pola tanam. Mamondol dan Sopani (2018) menyatakan bahwa terdapat perbedaan produksi, penerimaan, biaya produksi, dan pendapatan usaha tani padi sawah metode SRI dan Tabela pada petani di Desa Tonusu Kecamatan Pamona Puselemba. Terdapat perbedaan koefisien variasi pendapatan petani yang menerapkan metode SRI dan Tabela. Koefisien variasi yang lebih tinggi pada metode Tabela mengindikasikan risiko yang lebih besar terhadap pendapatan petani dibandingkan pada metode SRI. Risiko krusial pada pola tanam Tabela disebabkan benih mudah hanyut pada musim hujan, sehingga petani perlu menanam benih ulang di samping itu penggunaan input juga berpengaruh terhadap risiko usaha tani. Berdasarkan perspektif input, pola tanam SRI memiliki risiko yang lebih kecil karena kesuburan tanah cenderung lebih terjaga dan serangan hama penyakit lebih dapat ditekan. Selanjutnya (Rama, 2016) Risiko produksi lahan basah lebih besar diakibatkan pada penggunaan input sarana produksi usaha tani yang lebih kompleks hal ini berbeda dengan lahan kering. Penggunaan input dan metode yang begitu kompleks merupakan konsekuensi yang perlu dipertimbangkan hal lain yang berpengaruh adalah ketersediaan air, ketergantungan lahan basah terhadap air 
sangat di tentukan guna meningkatkan proses pertumbuhan tanaman. Hal serupa juga di sampaikan (Suharyanto, Rinaldy, \& Ngurah Arya, 2015) bahwa risiko produksi usaha tani padi sawah pada musim hujan lebih tinggi dibandingkan dengan usaha tani padi sawah pada musim kemarau, curah hujan merupakan faktor yang meningkatkan risiko. Pada musim hujan tingkat serangan penyakit lebih tinggi dibandingkan dengan musim kemarau, selain itu pada musim hujan intensitas radiasi matahari juga lebih rendah dibandingkan musim kemarau yang tentunya akan berpengaruh terhadap proses fotosintesis.

Sedangkan Asbullah dkk. (2017) yang menerangkan bahwa hubungan antara lama penerapan usaha tani padi organik dengan risiko masih terhindar dari kerugian karena besarnya risiko pendapatan yang dihadapi tidak lebih dari $50 \%$ dari rata-rata pendapatannya. Namun ditemukan risiko pendapatan yang diakibatkan penerapan standar operasional prosedur pengendalian hama yang kurang optimal Sementara itu terdapat hubungan pada variabel luas lahan, Nilai perbandingan risiko terhadap rata-rata pendapatan yang diperoleh yang ada di lahan sempit milik petani adalah sebesar 47,53\%, pada lahan sedang sebesar $34,61 \%$ dan pada lahan luas sebesar $24,45 \%$. Artinya semakin luas lahan usaha tani mengakibatkan risiko semakin berkurang hal ini di sebabkan dari komponen biaya tetap yang dikeluarkan dalam usaha tani padi organik terdiri dari alat sodong (alat untuk membersihkan gulma pada tanaman padi organik) dan biaya pajak tanah. Menurut Prihtanti (2014), dalam asbullah (2017) semakin luas lahan usaha tani padi organik yang dijalankan maka semakin rendah risiko pendapatan yang dihadapi petani Hal tersebut dikarenakan semakin luas lahan usaha tani maka biaya tetap yang dikeluarkan semakin rendah.

Analisa risiko padi tidak hanya dipandang berdasarkan perspektif usaha tani saja, namun juga dapat dipandang berdasarkan perspektif asuransi. Keterkaitan antara risiko usaha tani padi dengan AUTP (Asuransi usaha tani Padi) telah dilaksanakan oleh (Saragih dkk., 2018b) yang menunjukkan bahwa peluang dan dampak terjadinya risiko di Desa Panca Arga dengan intensitas kerusakan $\geq 75 \%$ masih jarang terjadi. Nilai pertanggungan yang ditetapkan AUTP tidak dapat menutupi total biaya yang dikeluarkan petani. Hal inilah yang menyebabkan kurangnya partisipasi petani padi untuk mengikuti program AUTP (Asuransi usaha tani Padi).

Ditinjau berdasarkan rangkuman beberapa penelitian di atas, dapat ditarik kesimpulan bahwa risiko usaha tani padi dapat dilihat dari berbagai perspektif. Secara umum hal-hal yang kemungkinan besar menjadi risiko produksi adalah bencana alam, cuaca dan iklim, gangguan OPT, topologi wilayah, dan permodalan. Risiko produksi padi antar pola 
tanam juga berbeda, selanjutnya risiko usaha tani padi juga dapat dilihat berdasarkan perspektif pendapatan, salah satu variabel yang sangat berpengaruh positif terhadap pendapatan adalah luas lahan. Bagi kedua pemangku kepentingan utama (petani dan perusahaan asuransi), tingkat risiko menjadi dasar analisa penerapan AUTP.

Penanggulangan risiko usaha tani padi di Indonesia

Penelitian Dwi (2018) Berdasarkan Peraturan Menteri Pertanian peserta AUTP adalah a) Petani yang memiliki lahan sawah dan melakukan usaha budidaya tanaman padi pada lahan paling luas 2 (dua) hektar, b) Petani penggarap yang tidak memiliki lahan usaha tani dan menggarap lahan sawah paling luas 2 (dua) hektar.

\section{Berdasarkan Kementrian Pertanian} (2017), bahwa AUTP memberikan jaminan atas kerusakan pada tanaman yang diasuransikan yang diakibatkan oleh banjir, kekeringan, dan serangan OPT dengan batasan-batasan sebagai berikut:

a. Banjir adalah tergenangnya lahan pertanian selama periode pertumbuhan tanaman dengan kedalaman dan jangka waktu tertentu, sehingga menurunkan tingkat produksi tanaman.

b. Kekeringan adalah tidak terpenuhinya kebutuhan air tanaman selama periode pertumbuhan tanaman yang mengakibatkan pertumbuhan tanaman tidak optimal, sehingga menurunkan tingkat produksi tanaman.

c. Organisme Pengganggu Tumbuhan (OPT) adalah organisme yang dapat mengganggu dan merusak kehidupan tanaman atau menyebabkan kematian pada tanaman pangan, termasuk di dalamnya:

(i) Hama Tanaman: Penggerek batang, wereng batang cokelat, walang sangit, tikus, dan ulat grayak dan keong mas.

(ii) Penyakit Tanaman: blast, bercak cokelat, tungro, busuk batang, kerdil batang, kerdil hampa, kerdil rumput/kerdil kuning dan kresek.

Ganti rugi diberikan kepada peserta AUTP apabila terjadi banjir, kekeringan dan atau serangan OPT yang mengakibatkan kerusakan tanaman padi yang dipertanggungkan dengan kondisi persyaratan: a.) Umur padi sudah melewati 10 hari (10 hari setelah tanam/HST). b.) Umur padi sudah melewati 30 hari (teknologi tabela). c.) Intensitas kerusakan mencapai $\geq 75 \%$ dan luas kerusakan mencapai $\geq 75 \%$ pada setiap luas petak alami.

Dalam AUTP, harga pertanggungan ditetapkan sebesar Rp. 6.000.000,- per hektar per musim tanam. Harga pertanggungan menjadi dasar perhitungan premi dan batas maksimum ganti rugi. Total premi asuransi sebesar Rp.180.000,- /ha/MT. Besaran bantuan premi dari pemerintah Rp.144.000,- /ha/MT dan sisanya swadaya petani Rp.36.000,- 
/ha/MT. Jika luas lahan yang diasuransikan kurang atau lebih dari 1 (satu) ha, maka besarnya premi (dan ganti rugi) dihitung secara proporsional. Polis asuransi diterbitkan untuk satu musim tanam dengan jangka waktu pertanggungan dimulai pada tanggal perkiraan tanam dan berakhir pada tanggal perkiraan panen (Kementrian Pertanian, 2017). Pelaksanaan AUTP melibatkan berbagai pihak/instansi. Secara umum, mekanisme pelaksanaannya dapat dilihat pada Gambar 1.

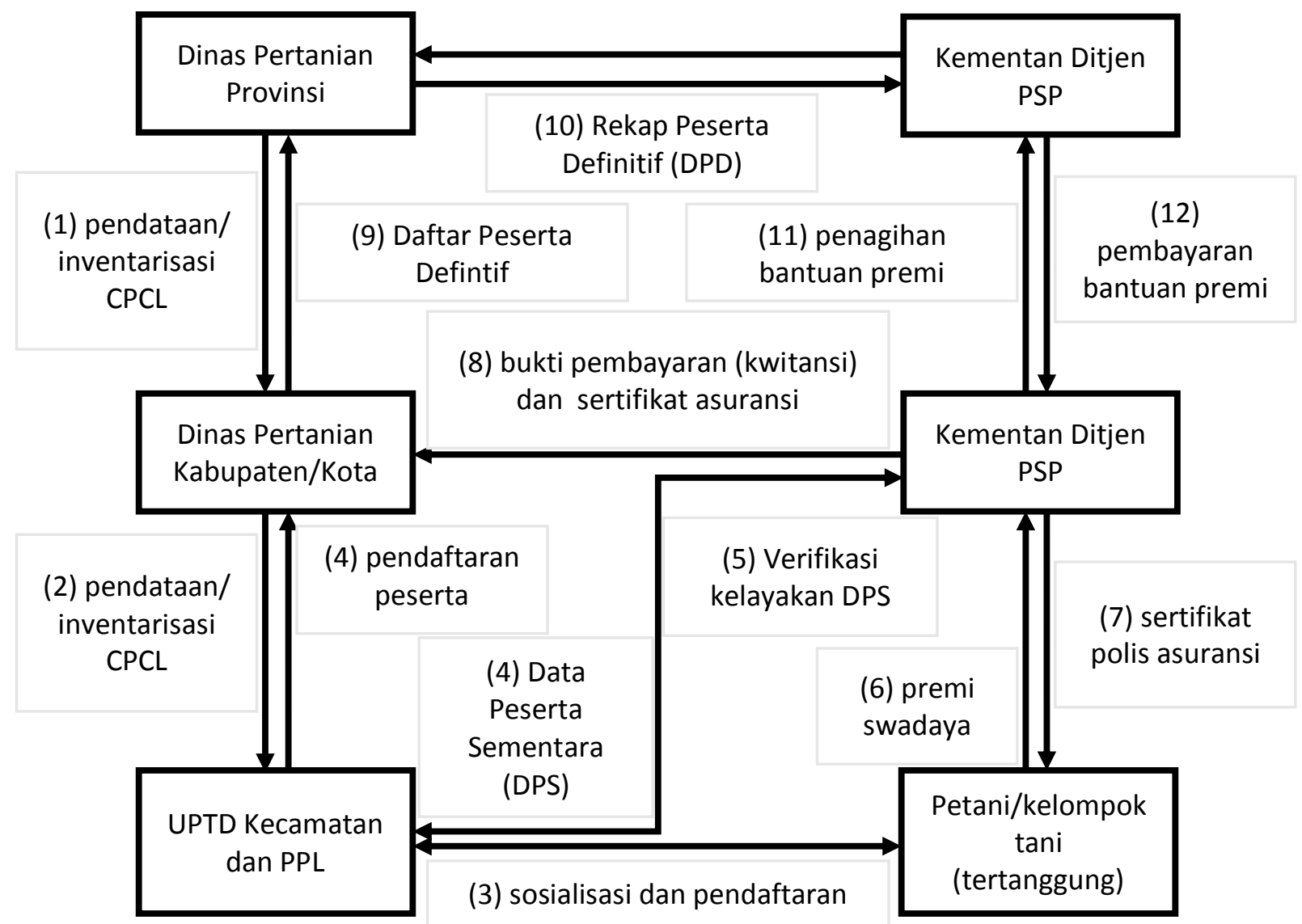

Gambar 1. Mekanisme pelaksanaan AUTP 2017

Banyak penanganan risiko yang harus disesuaikan berdasarkan perspektif risikonya. Saputra (2017) menyatakan bahwa petani di Desa Gragilan-Purworejo memilih cara penanggulangan risiko sebagai berikut: 1) sebelum melakukan usaha tani padi petani atau sebelum mengalami risiko, petani terlebih dahulu membuat perencanaan bersama kelompok tani dan penyuluh pertanian, 2) saat masa produksi apabila terserang hama dan penyakit petani lebih banyak memilih untuk membasmi hama dengan menggunakan pestisida yang lebih cepat dan terbukti, walaupun petani sudah mengetahui dampaknya, dan 3) setelah mengalami risiko petani tetap melakukan/menyelesaikan usaha taninya walaupun produksi padi tidak sesuai dengan yang diharapkan. Selanjutnya Asbullah (2017) menerangkan risiko fluktuasi harga dapat diatasi dengan pola kemitraan di mana petani melakukan kontrak kerja sama dengan gapoktan yang menjanjikan harga yang stabil 
sehingga risiko pendapatan dengan biaya produksi dapat teratasi. Semakin luas lahan usaha tani padi organik mengakibatkan risiko semakin berkurang dikarenakan semakin luas lahan usaha tani maka biaya tetap yang dikeluarkan semakin rendah. Ketika luas lahan cenderung lebih sulit untuk disiasati, petani dapat menyiasati pengadaan biaya investasi pada pengadaan Alsintan melalui kelompok tani.

Penelitian-penelitian perbandingan risiko berdasarkan pola tanam padi seperti yang telah dilaksanakan oleh Mamondol (2017) penting untuk digencarkan. Semakin banyak penelitian serupa dan membandingkan semakin banyak pola tanam, maka akan ditemukan pola tanam padi dengan risiko paling rendah. Diketahuinya pola tanam dengan tingkat risiko paling rendah harus dilanjutkan dengan perbandingan kesesuaian produksi, sehingga pada akhirnya ditemukan pola tanam anjuran yang minim risiko namun tetap berpotensi memiliki tingkat produksi relatif tinggi.

Di samping itu AUTP masih menjadi salah satu solusi penanggulangan risiko usaha tani padi. Saragih (2018) menyatakan bahwa bahwa risiko perubahan iklim pada usaha tani padi di Desa Panca Arga-Asahan masih relatif kecil, yang mengindikasikan efektifnya fungsi saluran irigasi. Dengan demikian pemeliharaan saluran irigasi sebaiknya dipertahankan sehingga dapat menekan risiko akibat perubahan iklim. Dengan kejadian rata-rata risiko $<20 \%$ dan total biaya produksi sebesar Rp7.595.664 - Rp12.109.351, maka penetapan ambang kerusakan $75 \%$ dengan biaya pertanggungan Rp6.000.000 dapat menjadi disinsentif bagi petani untuk mengikuti AUTP.

\section{KESIMPULAN}

Faktor-faktor yang mempengaruhi produksi usaha tani padi di Indonesia dengan berbagai kondisi adalah luas lahan, biaya pupuk, pestisida, tenaga kerja, bibit/benih, umur petani, modal, dan penyuluhan. Faktor yang paling dominan berpengaruh adalah luas lahan. Secara umum faktor risiko potensial adalah bencana alam, perubahan cuaca dan iklim, gangguan OPT, topologi wilayah, dan permodalan. Risiko produksi padi antar pola tanam juga berbeda, terbukti perbedaan risiko antara pola tanam SRI dan pola tanam Tabela. Variabel lain yang berpengaruh nyata terhadap risiko pendapatan usaha tani padi adalah luas lahan. Penanggulangan risiko usaha tani padi disesuaikan berdasarkan perspektif risiko. Pada aspek internal, risiko dapat diantisipasi melalui peningkatan kapasitas petani. Pada aspek eksternal, risiko masih memungkinkan ditanggulangi melalui AUTP.

\section{SARAN}

Guna mengurangi risiko perubahan iklim disarankan untuk memelihara dan membangun saluran irigasi guna menjaga ketersediaan air tetap stabil, selanjutnya perlu campur tangan 
pemerintah dalam menanggulangi risiko dengan melakukan penyuluhan yang lebih giat, penggunaan teknologi, dan pemodalan. Pada kasus AUTP pertanggungan yang dapat menutupi biaya produksi yang keluarkan petani agar maksimal serta dapat menarik minat petani dalam mengikuti AUTP sehingga disinsentif bisa dihindari dari pihak petani.

\section{DAFTAR PUSTAKA}

Asbullah, M., Hapsari, T. D., \& Sudarko, S. (2017). Analisis risiko pendapatan pada usaha tani padi organik di desa Lombok Kulon kecamatan Wonosari kabupaten Bondowoso. JSEP (Journal of Social and Agricultural Economics), 10(2), 35-42. https://doi.org/10.19184/jsep.v10i2.4552

Badan Pusat Statistik [BPS]. (2012). Berita resmi statistik, perkembangan nilai tukar petani dan harga produsen gabah. Badan Pusat Statistik.

Dwi, N. S. (2018). Persepsi dan kesediaan membayar (willingness to-pay) petani terhadap asuransi usaha tani padi di kecamatan Akabiluru kabupaten Lima Puluh Kota [Diploma, Universitas Andalas]. http://scholar.unand.ac.id/36899

Hera, E. de la, Martinez, M., \& Gómez, M. (2013). Influence of flour particle size on quality of gluten-free rice bread. LWT Food Science and Technology, 54(1), 199206. https://doi.org/10.1016/j.Iwt.2013. 04.019

Kementrian Pertanian. (2017). Pedoman umum asuransi tani padi tahun 2017. Direktorat Prasarana dan Sarana Pertanian.

Kurniati, D. (2014). Analisis risiko produksi dan faktor-faktor yang mempengaruhinya pada usaha tani jagung di kecamatan Mempawah Hulu kabupaten Landak. Jurnal Social Economic of Agriculture, 1(3), 60-68. https://doi.org/10.26418/ j.sea.v1i3.4366
Latham, A. J. H. (2013). Rice: The Primary Commodity. Routledge.

Mamilianti, W., Hanani, N., Mustadjab, M. M., \& Asmara, R. (2019). Risk preference of farmers and production input allocation of potato farming in Tengger highland, Indonesia. EurAsian Journal of BioSciences, 13(2), 1777-1783.

Mamondol, M. R. (2018). Analisis risiko usaha tani padi sawah metode system of rice intensification (SRI) dan tanam benih langsung (tabela) di desa Tonusu kecamatan Pamona Puselemba. https://doi.org/10.31227/osf.io/dkg6b

Mariyono, J. (2015). Green revolution- and wetland-linked technological change of rice agriculture in Indonesia. Management of Environmental Quality: An International Journal, 26(5), 683-700. https://doi.org/10.1108/MEQ-07-20140104

Miller, R. L., \& Meiners, R. E. (2000). Teori mikroekonomi intermediate. PT Raja GrafindoPersada.

Moongngarm, A., Daomukda, N., \& Khumpika, S. (2012). Chemical compositions, phytochemicals, and antioxidant capacity of rice bran, rice bran layer, and rice germ. APCBEE Procedia, 2, 73-79. https://doi.org/10.1016/j.apcbee.2012.0 6.014

Panuju, D. R., Mizuno, K., \& Trisasongko, B. H. (2013). The dynamics of rice production in Indonesia 1961-2009. Journal of the Saudi Society of Agricultural Sciences, 12(1), 27-37. https://doi.org/10.1016/ j.jssas. 2012.05.002

Prihtanti, 2014. Analisis risiko berbagai luas penguasaan lahan pada usaha tani padi organik dan konvensional. AGRIC 26 (1): 34-35.

Rama, R., Nurliza, N., \& Dolorosa, E. (2016). Analisis risiko produksi usaha tani padi lahan basah dan lahan kering di kabupaten Melawi. Jurnal Social Economic of Agriculture, 5(1), 73-88. https://doi.org/10.26418/j.sea.v5i1.1506 2 
Saputra, R. (2017). Analisis risiko usaha tani padi di daerah perbukitan di desa Kragilan kecamatan Gebang kabupaten Purworejo [Thesis, Universitas Muhammadiyah Purworejo]. http://repository.umpwr.ac.id:8080/hand le/123456789/896

Saragih, I. R., Chalil, D., \& Ayu, S. F. (2018). Analisis risiko produksi padi dalam pengembangan asuransi usaha tani padi (AUTP) (desa Panca Arga, kecamatan Rawang Panca Arga, kabupaten Asahan). Jurnal AGRISEP Kajian Masalah Sosial Ekonomi Pertanian dan Agribisnis, 17(2), 187-196. https://doi.org/10.31186/ agrisep.17.2.187-196

Suharyanto, S., Rinaldy, J., \& Arya, N. N. (2016). Analisis risiko produksi usaha tani padi sawah di Provinsi Bali. AGRARIS: Journal of Agribusiness and Rural Development Research, 1(2), 70-77. https://doi.org/ 10.18196/agr.1210
Suprapto, E. (2010). Analisis faktor-faktor yang mempengaruhi usaha tani padi organik di Kabupaten Sragen [Thesis, Sebelas Maret University].

https://digilib.uns.ac.id/dokumen/13218/ Analisis-faktor-faktor-yang-

mempengaruhi-usaha tani-padi-organikdi-Kabupaten-Sragen

Umadevi, M., Pushpa, R., Sampathkumar, K. P., \& Bhowmik, D. (2012). Rice-traditional medicinal plant in India. Journal of pharmacognosy and phytochemistry, 1(1), 6-12.

Zakirin, M., Yurisinthae, E., \& Kusrini, N. (2013). Analisis risiko usaha tani padi pada lahan pasang surut di Kabupaten Pontianak. Jurnal Social Economic of Agriculture, 2(1), $\quad$ 75-84. http://dx.doi.org/10.26418/j.sea.v2i1.512 2

Zed, M. (2008). Metode peneletian kepustakaan. Yayasan Obor Indonesia. 